\title{
Characterizing Spatiotemporal Patterns of Mangrove Forests in Can Gio Biosphere Reserve Using Sentinel-2 Imagery
}

\author{
Hoa T. Le ${ }^{1}$, Thuong V. Tran ${ }^{1, *}$, Sangay Gyeltshen ${ }^{2}{ }^{\oplus}$, Chau P. T. Nguyen ${ }^{1}$, Duy X. $\operatorname{Tran}^{3}$, \\ Tung H. Luu ${ }^{4}$ and Man B. Duong ${ }^{4}$ \\ 1 Faculty of Geography, University of Social Sciences and Humanities, VNU-HCM, Ho Chi Minh City 70000, \\ Vietnam; hoalethanh@hcmussh.edu.vn (H.T.L.); ntpchau@hcmussh.edu.vn (C.P.T.N.) \\ 2 Department of Remote Sensing and Geographic Information System, APECS Consultancy Services, \\ Thimphu 11001, Bhutan; sangye89@gmail.com \\ 3 School of Agriculture and Environment, College of Sciences, Massey University, Palmerston North 4442, \\ New Zealand; D.Tran@massey.ac.nz \\ 4 Ho Chi Minh City Institute of Resources Geography, Vietnamese Academy of Science and Technology, \\ Ho Chi Minh City 70000, Vietnam; lhtung@hcmig.vast.vn (T.H.L.); dbman@hcmig.vast.vn (M.B.D.) \\ * Correspondence: tvthuong@hcmussh.edu.vn
}

Received: 11 May 2020; Accepted: 10 June 2020; Published: 12 June 2020

Featured Application: This study proposes the features of mangrove forest variations in relation to anthropogenic activities under the forms of land use land cover changes around three ecological zones of a Biosphere Reserve area, using Sentinel-2 Imagery and spatial regression approaches that have wide application in natural resources, land use planning, and environmental management.

\begin{abstract}
This study aimed at evaluating the spatiotemporal patterns of mangrove forest variations for three ecological zones of the Can Gio biosphere reserve (i.e., core, buffer, and transition zones) and its relation to land use/land cover changes. Time series Sentinel-2 Imagery-which presents the Normalized Different Vegetation Index (NDVI), obtained through the Google Earth Engine and Overlap Similarity Algorithm-was used to characterize vegetation cover in the study area. Furthermore, the Cohen's Kappa agreement was applied to examine the accuracy of mangrove classification, and the Mann-Kendal (MK) significance was used to analyze the spatiotemporal trends of mangrove forests. The results showed that an NDVI value greater than 0.3 recorded the reflected signal of mangrove population in the study area with an $O$-index greater than 0.85 . A Cohen's Kappa statistic of agreement of 0.7 and an overall classification accuracy of $83 \%$ was obtained. Regarding the trend in mangrove forest patterns, an increase in area of 669 ha and 579 ha explored at the buffer and core zones, respectively, while the largest declined mangrove area of 350 ha was investigated at the buffer zone, followed by a transition at 314 ha during the study period due to the interconversion of shrimp farming and the expansion of built-up areas. Moreover, the study also described the negative impacts of the sea-encroached urban-tourism zone on mangrove patterns in the foreseeable future. The results from this study will act as a basic fundamental authentic report for local governments in proposing strategies for the shielding of mangrove forests and economic development from negative consequences in foreseeable future.
\end{abstract}

Keywords: NDVI; overlap similarity algorithm; satellite imagery; LULC; coastal area 


\section{Introduction}

Mangrove forests are widely located in the intertidal zone with an estimated area of 152,361,000 ha in tropical and sub-tropical shorelines of the world [1-3]. The mangrove ecosystem is significant as an ecological service in coastal neighborhoods through providing natural resources to local livelihoods (i.e., provision of fuel, food, timber, and construction materials) [4,5], and being a habitat for diversity of flora and fauna [6]. Moreover, mangrove forests also play crucial roles in coastal stabilization and protection [7] by contributing to the reduction of greenhouse gas emission, and mitigating the negative effects of global warming by a considerable extent [8]. However, the mangrove ecosystem has been severely degraded due to the negative impacts of population growth, industrialization, urban expansion, and agricultural activities $[2,9,10]$. Therefore, the need to map and monitor mangrove forest patterns and dynamics is both necessary and urgent.

The Can Gio Mangrove Biosphere Reserve, which covers an area of 750 square kilometers, is considered as a "green lung" of Ho Chi Minh City (HCMC) [8,11]. During the Vietnam War period from 1954 to 1975, the mangrove forest in the study area was destroyed, however, a large scale of reforestation has been implemented by the HCMC Forestry Department since after 1977 [11,12]. The effort for forest recovery was resolved in the year 2000, when United Nations Educational Scientific and Cultural Organization (UNESCO) recognized the Can Gio mangrove forest as a World Biosphere Reserve, making it the first biosphere reserve region in Vietnam [13]. However, under high demands for economic development (i.e., construction of apartments and tourism facilities, and shrimp farming activities), mangrove sustainability around buffer and transition zones has been crucially influenced by anthropogenic activities in recent years [14]. The expansion of built-up areas and an increase in tourism development in coastal areas in Ho Chi Minh City [15-17] have exerted negative impacts on vegetation cover. Moreover, an enlargement of sea-encroached urban-tourism zones in Can Gio in 2025 based on Decision No. 3800 by the People's Committee of Ho Chi Minh City might cause critical damage on the mangrove area [18]. Therefore, it is necessary to implement an assessment of mangrove change following the conversion of land use purposes in the Can Gio district.

The advantages of remote sensing have been reported as a practiced database resource by a large number of studies in mapping mangroves with lower cost, faster speed, and a larger scale, compared to traditional field investigations $[2,6,19,20]$. Additionally, following remotely sensed data, there is a variety of multispectral satellite imagery techniques for spectral indices performance and the determination of mangrove conditions, such as Landsat [21,22], Advanced Spaceborne Thermal Emission and Reflection Radiometer (ASTER) [23,24], Moderate Resolution Imaging Spectroradiometer (MODIS) [25], and Pleiades [26]. Recently, several studies have applied Landsat [27], ALOS PALSAR-2 [28], and Satellite Pour l'Observation de la Terre (SPOT) [8] combined with field observation to characterize mangrove species in the study area. Compared to other digital resource databases, Sentinel-2 provides a greater extent of the distribution of vegetation over the coastal region [29] with a high spatial resolution of $10 \mathrm{~m}$, a high temporal resolution, a five day re-visit interval, and it is free of charge. These benefits make Sentinel-2 an efficient data source when examining the spatiotemporal aspects of a mangrove forest, and it is especially valuable in the context of developing countries, where the budget for this kind of work is limited.

Major methods for monitoring mangrove forests include visual interpretation, supervised classification, unsupervised classification, neural network classification, and the object-based classification method $[8,20,30]$. In the study area, a pixel-based classification approach was applied for mapping and monitoring mangrove coverage [8,31], but most of these studies are limited in the long-term monitoring of mangrove. For example, Pham et al. (2019) [8] applied two SPOT datasets (in 2000 and 2011) with a spatial resolution of $10 \mathrm{~m}$ to analyze the changes in mangrove cover, but the spatiotemporal trends and variations were not presented in detail. For instance, the research described changes in mangrove areas for the whole study site, but it did not investigate the pattern and rate of change per pixel. In addition, the users must pay a substantial cost for acquiring SPOT data to conduct the research, while the spatial resolution is similar to Sentinel-2 imagery. Moreover, spectral 
indices have been applied widely for the identification and monitoring of mangrove patterns from non-mangrove vegetation classes in areas rich in mangrove diversity, and using time series to examine spatiotemporal variations is also more justifiable compared to the straight-forward statistics methods (e.g., overlaying two images) [20,32].

The Normalized Difference Vegetation Index (NDVI) is an indicator which has been used in various applications related to ecosystem monitoring [33]. The NDVI was developed by Rouse et al. (1974) [34], using reflectance values of Red and Near-Infrared (NIR) bands of the multispectral electromagnetic spectrum. It quantifies the variations in chlorophyll content via absorption, and in spongy mesophyll via reflected near-infrared radiation within the vegetation canopy. Previous studies applied the NDVI widely to investigate mangrove forests at both global [35] and regional scales [30,36]. Recently, the Google Earth Engine (GEE), an online data provider portal that allow users to access a wide range of time series satellite imagery, has enabled better support to research communities in undertaking Earth observation studies [37,38]. This tool is currently available on request to a number of groups for testing and developing applications [39]. The GEE Application Program Interface (API) enables users to access and develop algorithms on the full Earth Engine data archive using Google's cloud computing and processing platform [37,39]. As such, using GEE facilitates a better performance on spectral vegetation indices for the examination of the pattern of mangrove forest variations.

Our study aims at answering the research question related to determining the effectiveness of using the multi-temporal NDVI derived from Sentinel-2 through the Google Earth Engine for mapping and monitoring the mangrove patterns. The specific objectives are to: (i) investigate the reflectance of the NDVI to mangrove coverage derived from Sentinel-2; (ii) characterize the spatial distribution of mangrove forests through three ecological zones of the Biosphere Reserve area; and (iii) assess the relationship between land-use change and variation in the mangrove forest area. The Can Gio district was selected as a case study to demonstrate the effectiveness of integrating time-series data and spatial analysis techniques for mangrove forest change monitoring and assessment. The results will provide an important basis for proposing appropriate strategies in mangrove ecosystem management and provide a reference for wider global application.

\section{Materials and Methods}

\subsection{Study Site Description}

Can Gio $\left(10^{\circ} 22^{\prime} 14^{\prime \prime} \mathrm{N}-10^{\circ} 40^{\prime} 09^{\prime \prime} \mathrm{N}\right.$; $\left.106^{\circ} 46^{\prime} 12^{\prime \prime} \mathrm{E}-107^{\circ} 00^{\prime} 59^{\prime \prime} \mathrm{E}\right)$ is a coastal district located southeast of Ho Chi Minh City and is a center for economy, culture, and education in Southern Vietnam (Figure 1). The district was recognized as the first Mangrove Biosphere Reserve (MRB) in Vietnam following the recognition in 2000 by UNESCO with an area over 75,000 ha, while the dominated forest by mangrove covers an area of 61,110 ha (accounted for $81.48 \%$ in total) $[8,12]$. Moreover, the area of the MRB is divided into three ecological zones: core, buffer, and transition with an area of 4721 ha, 41,139 ha, and 29,880 ha, respectively.

Based on the frequency of inundation, the topography of Can Gio is categorized into four groups including daily flooded lowland $(0-0.5 \mathrm{~m})$, monthly flooded lowland $(0.5-1.0 \mathrm{~m})$, multi-year flooded lowland (1.0-2.0 m), and unflooded upland (2.0 m above) [12,40] (Figure 1). The climatic conditions border the sub-equator and monsoon zone with two separate seasons. The average temperature and humidity level at the study area is $28.7^{\circ} \mathrm{C}$ and $72 \%$ with average annual precipitation of $1760.6 \mathrm{~mm}$. The lithological characteristics of the study area are mostly Holocene sediments over flat terrain topography [41].

Most of the local people residing over the district depend directly or indirectly on mangrove forest services. The economic activities in the Can Gio mainly concentrate on sea food, such as fisheries, catching crabs, mollusks, and the production of salt, with the least amount of agricultural practices. The mangrove forest is a habitat for animals that live inside and nearby the sea, and it significantly reduces sea level rise and the impact of climate change in several measurements [41,42]. 


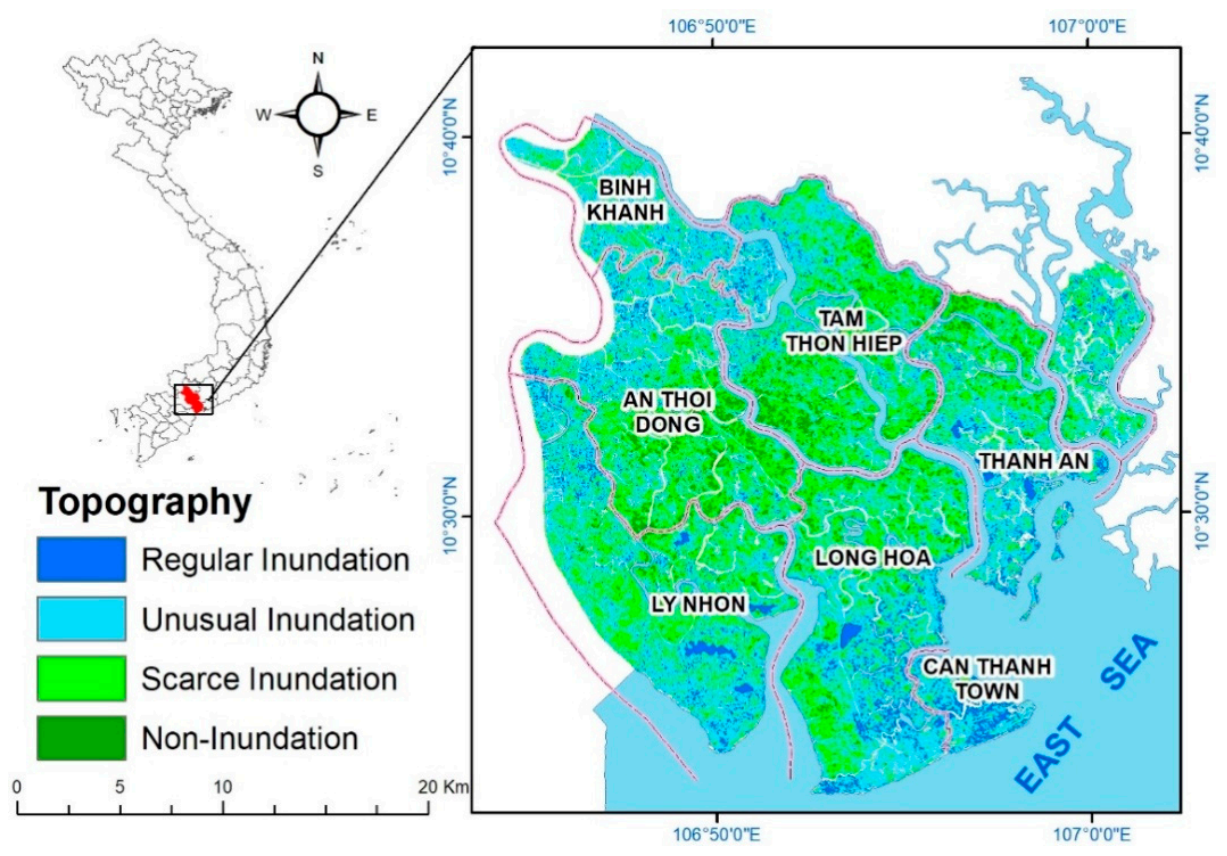

Figure 1. Location and zone ranges of elevation in study area.

\subsection{Sentinel Satellites Imagery}

Besides Landsat 8 OLI imagery launched by National Aeronautics and Space Administration (NASA) in 2013, a pair of identical satellite (Sentinel-2A and -2B) was launched in 2015 and 2017, respectively by ESA's European Space Operations Centre (ESOC) Darmstadt, Germany under same orbit in Wide Swath mode providing greater extent in distribution of vegetation over the coastal region [29]. The cloud free Sentinel-2 imagery with 13 acquired spectral bands was rectified in terms of radiometric and atmospheric correction. In addition to the temporal resolution, with a spatial resolution of $10 \mathrm{~m}$, Sentinel-2 products are appropriate as they enable us to map mangrove vegetation at a scale of 1:20,000 [43]. This study proposed Sentinel-2 imagery for the characterization of mangrove coverage at district level.

\subsection{Normalized Difference Vegetation Index}

The Normalized Difference Vegetation Index (NDVI) is a unitless numerical indicator for the type of live vegetation grown over the regions which used Red and NIR band of electromagnetic spectrum [34]. It plays a vital role in the identification of healthy vegetation where live vegetation absorbed red and green with more amount of NIR light, thus appearing as deeply red in false color composite (FCC). Denser plants over the region appear darker in red and vice versa, whereas sparse or unhealthy vegetation mostly reflect the visible light and a lower amount of NIR light, appearing grey in tone. It also depicts the presence of chlorophyll pigments within the plants, and provides an anomaly of the growing season which ultimately provides clues for desertification and drought conditions. The relationship between the production of vegetation and NDVI was well established theoretically and empirically by Schmid (2017) [44]. The NDVI can be mathematically defined as follows:

$$
\mathrm{NDVI}=\frac{\mathrm{NIR}-\mathrm{R}}{\mathrm{NIR}+\mathrm{R}}
$$

The value of NDVI ranges from -1 to +1 . The increasing values from 0 to +1 depict the presence of vegetation, and near +1 indicates the denser vegetation covered in the area. If the value decreases beyond 0 to -1 , it represents the present of bare land, water bodies, ice, snow and manmade 
features $[10,45]$. In this study, the Digital Number (DN) value of the NDVI images are categorized from low density to high density as per Table $1[46,47]$.

Table 1. Categories of the Normalized Different Vegetation Index (NDVI) density.

\begin{tabular}{cc}
\hline The DN Value & NDVI Density \\
\hline-1 to +0.1999 & No or almost no vegetation \\
+0.2 to +0.2999 & Low density vegetation \\
+0.3 to +0.3999 & Medium density vegetation \\
+0.4 and above & High density vegetation \\
\hline
\end{tabular}

\subsection{Google Earth Engine}

Google Earth Engine (GEE) is the most popular cloud-based platform for carrying out detailed image analysis using JavaScript API (application programming interphase) and an online Integrated Development Environment (IDE) code editor. The GEE is a modest platform where coder/users do not require satellite imagery to be downloaded and analysis is performed over the system (https://earthengine.google.com/). It allows the coder to access the whole function available with GEE without authorization, performing multi-time series analysis by distributing the workloads within different CPUs inside the datacenters, which mitigates the need for optimum high configuration workstations or systems to process thousands of planetary images within the timeframe [44]. The detailed scripts and components on importing the imagery to cloud computing platform (GEE) for analyzing NDVI time series was clearly demonstrated by Schmid (2017) [44]. In this study, the GEE was used to derive and perform long-term time series analysis of NDVI using red and NIR bands of the electromagnetic spectrum stated in Equation (1) within the cloud mask during the 2015-2019 period.

\subsection{Overlap Similarity Algorithm}

In this study, the NDVI shown mangrove patterns are treated as training samples and the status of mangrove populations, provided by the Management Board of Can Gio Mangrove Biosphere Reserve, is used as a testing sample. For the determination of the signals of the NDVI that show the mangrove population, the overlap similarity algorithm was applied. Overlap similarity is considered as a correlation coefficient in conducting a spatial correlation between two variables [48] and it stretches a decision case [49]. It is defined as the size of the intersection between two sets, divided by the size of the smaller of the two sets [50]. The formula of overlap similarity is calculated using Equation (2):

$$
O(A, B)=\frac{|A \cap B|}{\min (|A|,|B|)}
$$

where $A$ and $B$ are the NDVI of mangrove and referenced mangrove, respectively.

First, a novel sampling method named controlled random sampling is adopted to generate the training sets. The controlled random sampling can reduce the overlap between the training and testing samples. Then, the super-pixel segmentation method is adopted to divide the Sentinel-2 imagery into many smoothed small classifications [51]. The training samples with the same label will be used to form a set. The overlap index assigns a real number between 0 and 1 to the similar dataset. A zero value means that the documents are dissimilar completely, whereas one indicates that the documents are practically identical [50]. Therefore, if the NDVI is a subset of mangrove references, which are supposed to be the status of mangrove species by management, or vice-versa, it shows the overlap coefficient value as 1 .

\subsection{Accuracy Assessment}

The accuracy assessment is the process of evaluating the preciseness of mangroves classification. This is completed by comparing the coincidence between classified data and the referenced data 
(i.e., ground truth). Cohen's Kappa agreement of statistics is used in the current study, which measures the reliability and agreement of two classified features within the category [52] defined by Equation (3):

$$
K=\frac{P_{o}-P_{c}}{1-P_{c}}
$$

where $P_{o}$ denotes proportional overall agreement of the observed mangrove and $P_{c}$ denotes the mangrove probability agreement by chance. The interpretation of Cohen Kappa values is interpreted by [53] and demonstrated at the Table 2 .

Table 2. Interpretation of Kappa values.

\begin{tabular}{cc}
\hline Value & Description \\
\hline Less than 0 & Less than chance agreement \\
\hline $0.01-0.2$ & Sigh agreement \\
\hline $0.21-0.40$ & Fair agreement \\
\hline $0.41-0.60$ & Moderate agreement \\
\hline $0.61-0.80$ & Substantial agreement \\
\hline $0.81-1.00$ & Almost perfect agreement \\
\hline
\end{tabular}

There were 300 random training samples over the three ecological zones in the study site collected using a hand-held Global Positioning System (GPS) device. At each reference location, the respective mangrove cover and coordinates were recorded. The selected data were then compared to the results of the reflected mangrove from NDVI. The result from the accuracy assessment provided the considerable statistical values in the classified mangrove for three ecological zones (i.e., core, buffer, and transition). If the results sustained above $80 \%$ accuracy, an application of the NDVI for mangrove classification with a threshold of 0.3 can be justified; however, if the result is beyond the expected accuracy, as indicated in the similar procedure, it shall be followed until a substantial agreement is obtained. Therefore, the validation process was obtained with $20 \%$ mismatch tolerance regarding the official mangrove inventories.

\subsection{Mann-Kendall Trend Analysis and Significant Test}

The Mann-Kendal (MK) significance test is a rank-based technique that can deal with the issues of seasonality, non-normality, missing values, and serial dependence [54]. This method is the same as a rank non-parametric test, which has been applied efficiently to analyze long term trends in hydro-meteorological variables [55-59]. Recently, the great availability of time-series remotely sensed data have enabled research communities to examine the spatiotemporal features of environmental changes $[60,61]$. The selection of this method is based on the fact that it has the advantage of being less sensitive to outliers over the parametric method [62]. Hence, the application of the MK significance test in the research quantifies the spatiotemporal variations of the mangrove cover in the study area. The MK test statistic $(S)$ is calculated in the following equations:

$$
\begin{gathered}
S=\sum_{i=1}^{n-1} \sum_{j=i+1}^{n} \operatorname{sgn}\left(\mathrm{NDVI}_{j}-\mathrm{NDVI}_{i}\right) \\
\operatorname{sgn}\left(\mathrm{NDVI}_{j}-\mathrm{NDVI}_{i}\right)=\left\{\begin{array}{c}
+1 \mathrm{NDVI}>0 \\
0 \mathrm{NDVI}=0 \\
-1 \mathrm{NDVI}<0
\end{array}\right.
\end{gathered}
$$

In the Equations (4) and (5), where $\mathrm{NDVI}_{i}$ and $\mathrm{NDVI}_{j}$ are the data values at times $i$ and $j(j>i)$, respectively and $n$ indicates the length of the dataset $(n=5)$. The following expression, as an assumption, is approximately normally distributed $\{\operatorname{variance}[\operatorname{var}(S)=1]$ and mean $(l=0)$ value\}. 


$$
\begin{aligned}
& \operatorname{var}(S)=\frac{n(n-1)(2 n+5)}{18} \\
& Z=\left\{\begin{array}{cl}
\frac{s-1}{\sqrt{\operatorname{var}(s)},} & \text { if } S>0 \\
0, & \text { if } S=0 \\
\frac{s+1}{\sqrt{\operatorname{var}(s)},} & \text { if } S>0
\end{array}\right.
\end{aligned}
$$

The calculated standard $Z$ value in the Equations (6) and (7) is compared with the standard normal distribution table with two-tailed confidence levels $(\alpha=0.05)$. If the calculated $Z$ is greater $|Z|>\left|Z_{1-\alpha}\right|$, the null hypothesis $\left(H_{0}\right)$ is invalid and therefore, the trend is statistically significant. Otherwise, the $H_{0}$ hypothesis is accepted, that the trend is not statistically significant, and there is no trend in the time series (trendless time series) [63]. A positive (negative) value of $Z$ signifies an upward (downward) trend.

\section{Results and Discussion}

\subsection{Potential of the NDVI in Analyzing Mangrove Condition}

The distribution of the average value of the Normalized Difference Vegetation Index (NDVI) in the space and the area of each NDVI category from 2015 to 2019 is presented in Table 3 and Figure 2, respectively. The solidity of vegetation (NDVI $>0.3$ ) mainly concentrated on the core zone and part of the buffer zone (accounting for 6321.22 ha and 28,375.48 ha, respectively), while the rest of the classifications (NDVI $<0.3$ ) were mostly distributed in the transition zone of the study area.

Table 3. The statistical area (ha) of NDVI categories through three ecological zones during the 2015-2019 period.

\begin{tabular}{ccccc}
\hline Level & Ecological Zones & Transition & \multirow{2}{*}{ Buffer } & Core \\
\hline & Lower than 0.2 & $12,685.91$ & $13,364.16$ & 1682.58 \\
& From 0.2 to 0.3 & 2229.38 & 995.73 & 92.89 \\
& From 0.3 to 0.4 & 2198.65 & 1341.00 & 131.08 \\
& Higher than 0.4 & 2502.80 & $27,034.48$ & 6190.14 \\
\hline
\end{tabular}

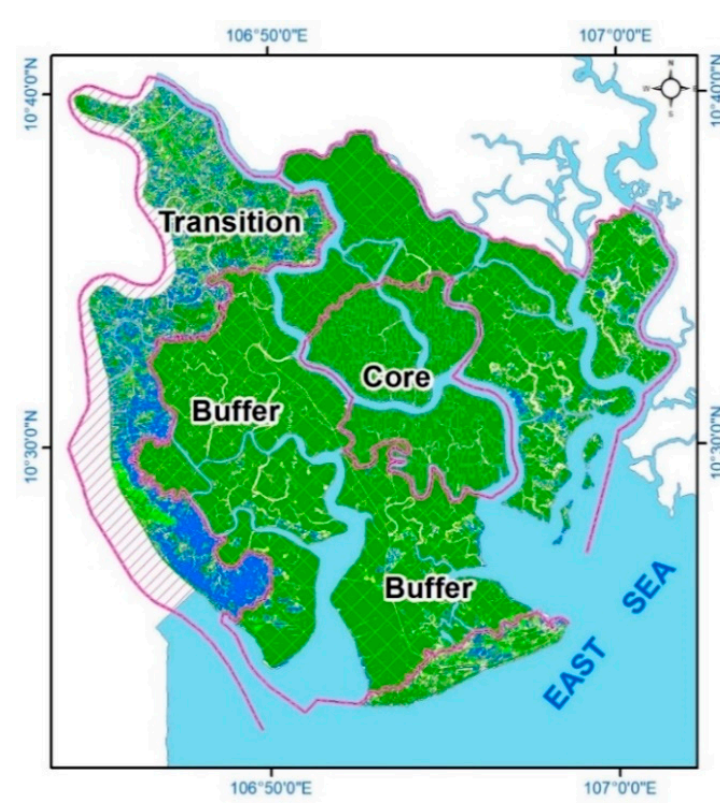

\section{Zone \\ Buffer \\ Core \\ Transition}

NDVI

None or Low Vegetation

Medium Vegetation

Dense Vegetation

- Highly Dense Vegetation

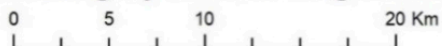

Figure 2. Spatial distribution of the mean Normalized Difference Vegetation Index (NDVI) classifications on three ecological zones during 2015-2019 period. 
The relationship between the training variable (NDVI $>0.3$ ) and testing variable (recorded mangrove) presented in Table 3 contributed a considerable validation of the NDVI to distinguish mangrove forests from non-mangrove. A high value of $O$-index above 0.85 showed the precise accuracy between the two mentioned variables (Table 4).

Table 4. The overlap index between mangrove of NDVI and referenced mangrove in 2015.

\begin{tabular}{cccc}
\hline & Transition & Buffer & Core \\
\hline$O$ index & 0.86 & 0.89 & 0.98 \\
\hline
\end{tabular}

Based on the overlap similarity algorithm between the NDVI and the mangrove status in 2015, the value of the mangrove forests derived from the NDVI was observed at above 0.3 , as presented in Figure 3 . A similarity in shape and distribution was illustrated in Figure $3 a, b$ between mangrove populations derived from NDVI indices and the referenced mangrove map. Previous studies implemented the mangrove classifications in the world using the NDVI, obtained from high-resolution Quick Bird multispectral satellite imagery with a $2.4 \mathrm{~m}$ spatial resolution and a ground truth measurement $[10,45]$. These studies also observed that the mangrove species obtained from the NDVI value was recorded as above 0.3. This enables us to find an appropriate signal of the spectral index for the characterization of mangrove coverage in the study area.
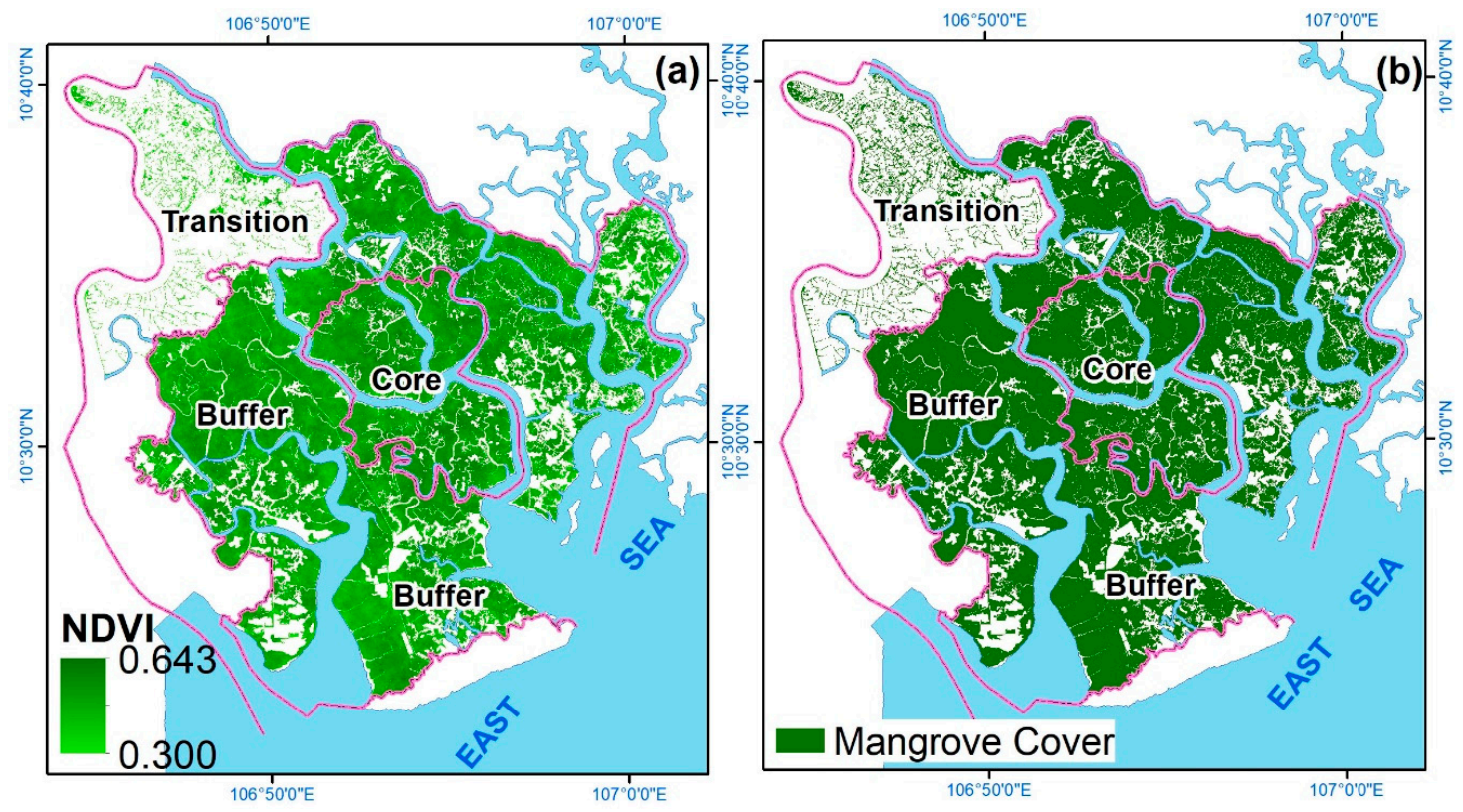

Figure 3. A comparison between (a) mangrove cover derived from NDVI value and (b) reference map of mangrove forests in 2015.

Additionally, this study concentrated on characterizing mangrove patterns through three primarily ecological zones of a biosphere reserve (i.e., transition, buffer, and core zones), while most of the previous studies mainly focused on recording mangrove population via its association with non-mangrove areas, or analysis based on the administrative boundary. Moreover, a validation of the NDVI showing mangrove population is presented in Table 5 .

A total of 300 randomly distributed ground truth training datasets of the mangrove area was collected using portable GPS. The substantial agreement was obtained with a Kappa statistic agreement of 0.7 and an overall classification accuracy of $83 \%$. The accuracy of the NDVI categories in this study reveals the applicability of the vegetation index derived from Sentinel-2 for mangrove patterns across space and time. 
Table 5. Confusion matrix of classification accuracy in 2015.

\begin{tabular}{ccccc}
\hline & Water Bodies & Non-Mangrove & Mangrove & User Acc \\
\hline Water Bodies & $\mathbf{7 4}$ & 14 & 2 & 90 \\
Non-Mangrove & 3 & $\mathbf{2 6}$ & 4 & 33 \\
Mangrove & 4 & 24 & $\mathbf{1 4 9}$ & 177 \\
Producer Acc & 81 & 64 & 155 & $\mathbf{3 0 0}$ \\
Overall Accuracy & \multicolumn{3}{c}{$\mathbf{8 3}$} \\
Kappa & & $\mathbf{0 . 7}$ \\
\hline
\end{tabular}

\subsection{Spatiotemporal Variations of Mangrove Forests in the Study Area}

There was a considerable change in the NDVI patterns and its influence on types of land cover during the 2015-2019 period in the study area, as shown in Figure 4. It is clear that the land cover dynamics occurred mainly in the transition zone and part of the buffer zone, while this pattern around the core area was more constant, with a greenness response. In addition, the study also focused on the other types of land use patterns in the study area (i.e., built-up, crop land, and residential area).
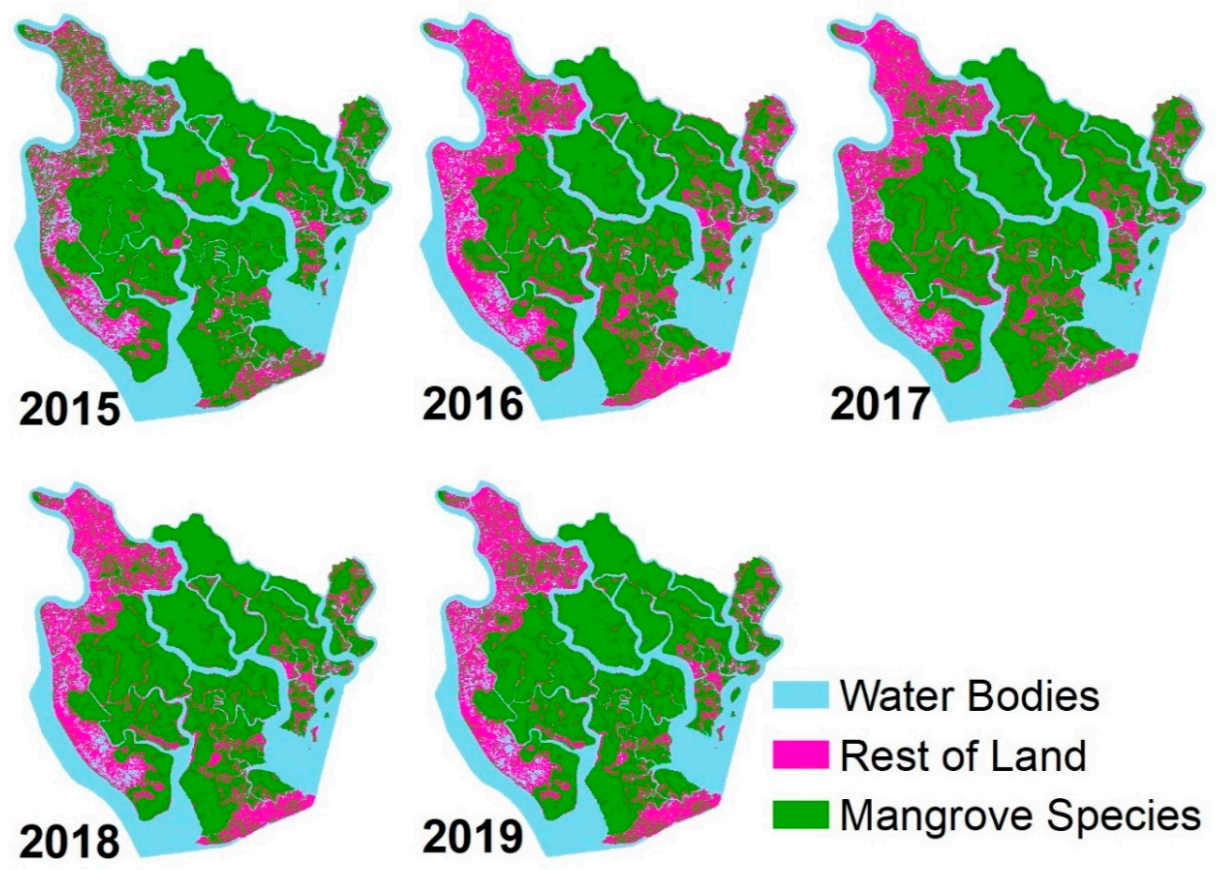

Figure 4. The change in types of land cover based on the annual NDVI classifications from 2015 to 2019.

Regarding the variations of mangrove areas in the ecological zones, a downward trend in total area was observed with 705 ha, while an upward trend was observed with 1248 ha between 2015 and 2019 (presented in Table 6). In particular, an increased area of 669 ha and 579 ha was observed at the buffer and core zones respectively, while this trend was constant in the transition zone from 2015 to 2019. On the other hand, the largest decline in mangrove area was investigated at the buffer zone, followed by the transition zone, at 350 ha and 314 ha, respectively. The spatial trend of mangrove patterns are also illustrated in Figure 5. The value of the factor increased most across the core and buffer zones with a $\mathrm{Z}$ value greater than zero in the central zone, whereas this pattern mainly decreased gradually from the buffer zone to the transition zone, where most socio-economic activities are practiced and are highly concentrated. Therefore, this demonstrates that activities of the local residents created influences on the mangrove area in the Mangrove Biosphere Reserve around the transition and buffer zones, despite the fact that the stable diversity of the mangrove coverage provides a large amount of ecosystem services (i.e., environment, economy, and society) to local residents [64]. 
Table 6. The significant changes in mangrove area through three ecological zones from 2015 to 2019 (ha).

\begin{tabular}{ccc}
\hline Zones & Increase & Decrease \\
\hline Transition & - & 314 \\
Buffer & 669 & 350 \\
Core & 579 & 40 \\
Total & $\mathbf{1 2 4 8}$ & $\mathbf{7 0 5}$ \\
\hline
\end{tabular}

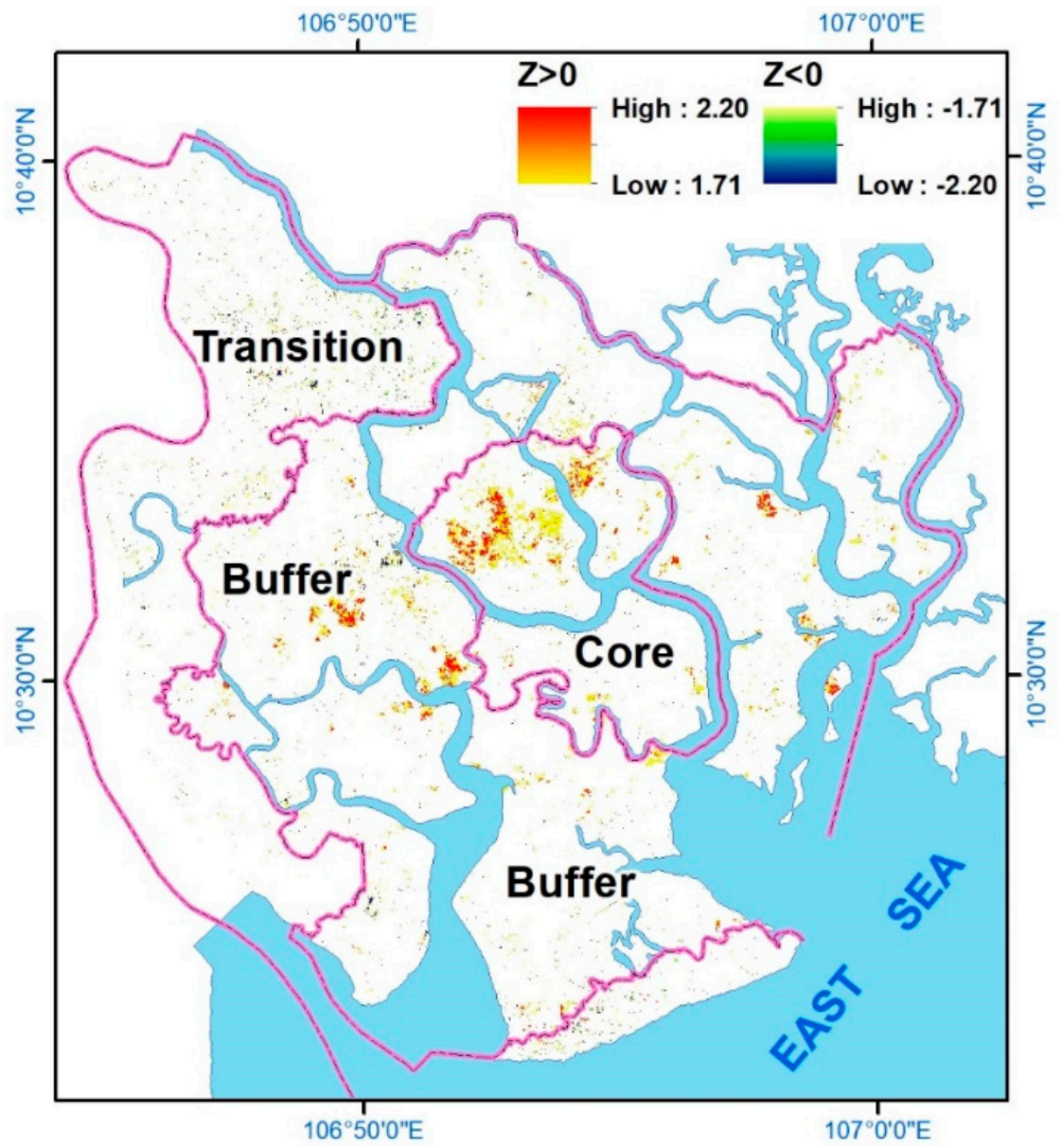

Figure 5. Spatiotemporal changes in mangrove population during the study period in Can Gio $(p<0.05)$.

Can Gio experienced war in 1965, destroying the mangrove vegetation over three ecological zones [12,40]. It was rehabilitated by the city government in 1977 [65], however, the mangrove species were still used for energy consumption, economic purposes, and construction. Until June 1999, the HCMC People's Committee issued a conservation letter-Decision No. 3172/QD-UB-CNN—to safeguard the forest, and the use of mangrove species for fuel purposes was totally prohibited [66]. The rehabilitated area of the Can Gio mangrove forest, until present, has accounted for 6.6 percent of the total core area. Therefore, most of the gathering activities in the forest have been completely prohibited for conservation purposes. However, the daily activities (mainly focusing on tourism, built-up areas, and shrimp farming) have exerted an impact on the mangrove variations in recent years. For instance, the number of visitors, demonstrated by Lap et al. (2018) [13], showed that 3.4 million tourists visited, with huge increases from 2011 to 2016.

The conversion in land use patterns is shown in Figure 6, and an analysis for each sector conversion is presented in Table 7. Most of the transformation in land use land cover (LULC) took place in the transition zone, apart from the buffer (mainly in Thanh An), focusing on the process between forests and other land. In addition, there was an area of 7.75 ha converted from forest to water bodies, while no 
transformation occurred regarding other components in the core zone. Moreover, about 133.03 ha and 366.9 ha of forest area switched to aquaculture and water bodies around the buffer zone. Furthermore, the built-up area was transformed from the forest area (about $6.97 \mathrm{ha}$ ), compared to the rest of the land. It can be concluded that the interconversion of LULC was aimed on the influence of economic development, which led to mangrove change, and these impacts gradually threaten the core zone.

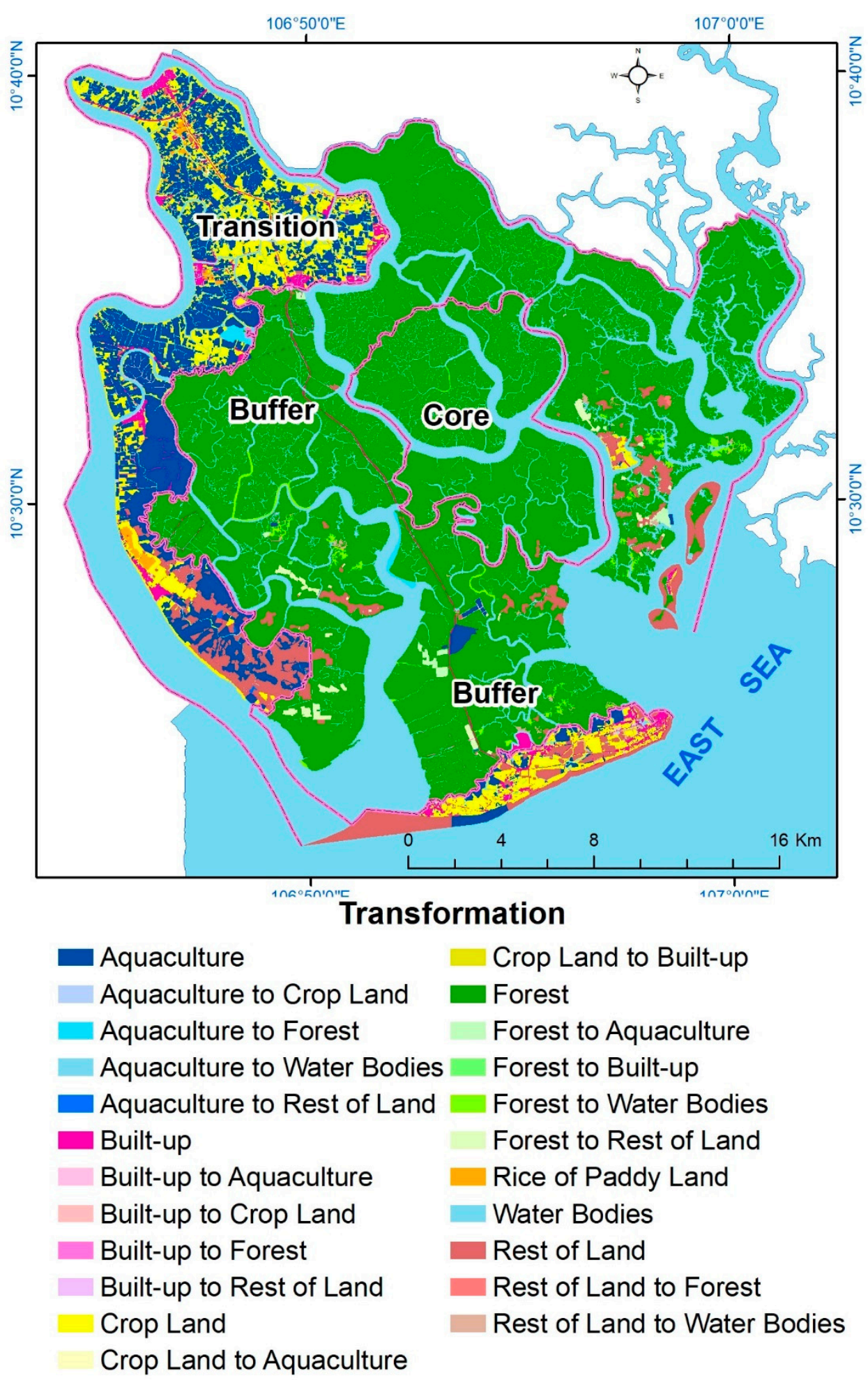

Figure 6. The land use/land cover change in the study area between 2015 and 2019. 
Table 7. The pattern of mangrove forest area followed the land use changes between 2015 and 2019 (ha).

\begin{tabular}{|c|c|c|c|c|}
\hline \multirow{2}{*}{ Transition of Land Use } & \multicolumn{3}{|c|}{ Zones } & \multirow{2}{*}{ Total Area } \\
\hline & Transition & Buffer & Core & \\
\hline Aquaculture & 6411.5 & 141.91 & 0 & 6553.41 \\
\hline Aquaculture to Crop Land & 19.37 & 0.02 & 0 & 19.4 \\
\hline Aquaculture to Forest & 81.08 & 66.21 & 0 & 147.29 \\
\hline Aquaculture to Water Bodies & 0.04 & 941.58 & 0 & 941.62 \\
\hline Aquaculture to Rest of Land & 13.24 & 1.46 & 0 & 14.7 \\
\hline Built-up & 824.52 & 170.75 & 0 & 995.28 \\
\hline Built-up to Aquaculture & 25.57 & 7.8 & 0 & 33.37 \\
\hline Built-up to Crop Land & 13.7 & 0.88 & 0 & 14.58 \\
\hline Built-up to Forest & 0.93 & 14.05 & 0 & 14.99 \\
\hline Built-up to Rest of Land & 19.84 & 7.93 & 0 & 27.77 \\
\hline Crop Land & 3869.62 & 93.27 & 0 & 3962.88 \\
\hline Crop Land to Aquaculture & 7.76 & 0.02 & 0 & 7.78 \\
\hline Crop Land to Built-up & 4.43 & 0.38 & 0 & 4.81 \\
\hline Forest & 1.19 & $27,487.57$ & 6143.17 & $33,631.93$ \\
\hline Forest to Aquaculture & 0 & 1330.3 & 0 & 1330.3 \\
\hline Forest to Built-up & 0 & 69.71 & 0 & 69,71 \\
\hline Forest to Water Bodies & 1.41 & 366.89 & 7.75 & 376.05 \\
\hline Forest to Rest of Land & 0 & 257.48 & 0 & 257.48 \\
\hline Rice of Paddy Land & 180.38 & 0 & 0 & 180.38 \\
\hline Water Bodies & 6225.83 & $12,393.61$ & 1934.28 & $20,553.72$ \\
\hline Rest of Land & 2247.67 & 1086.86 & 9.81 & 3344.34 \\
\hline Rest of Land to Forest & 1.54 & 11.94 & 0 & 13.48 \\
\hline Rest of Land to Water Bodies & 62.59 & 62.78 & 0 & 125.36 \\
\hline Total Area & $20,012.21$ & $44,513.1$ & 8095.01 & $72,622.62$ \\
\hline
\end{tabular}

According to [67], there was a varying perception among local farmers on mangrove vegetation. The fishermen clearly understood the negative influences of forest degradation, while the large group of aqua-farmers ignored the regulation of forest protection and management. Moreover, a weakness of strategies and management in the planning of livelihood conversion exerted negative impacts on the mangrove population [68-70]. Furthermore, it is necessary to mention a proposed project of the local government for ecotourism development $[17,18]$, well-known as the sea-encroached urban-tourism zone with a total area of 2870 ha, which is being conducted in Can Thanh town, located in the buffer zone (presented in Figure 7). A large number of mangrove species will be destroyed around the mentioned project for the construction of the supporting infrastructure (i.e., resort, bridge, road, and entertainment services) as well as to connect the local function sites for ecotourism development.

It can be demonstrated that a large number of investors have a demand for earning benefits from the mangrove area because of its ecological and economic value [64]. However, the change in LULC in the study area provided evidence for consequences of anthropogenic factors on mangrove dynamics, and this also contributes to the control of forest management in the future. For instance, the enlargement of intensive aquaculture in the transition zone, and especially in the buffer zone, has led to a decline in mangrove area, water pollution, and the spatial distribution of species in water bodies [8]. Moreover, the location of the new ecotourism project in the south pole of the forest may 
pose a threat to the diversity of mangrove species, or even prevent new immigrant species in the near future. This will be affected by the sustainability of ecosystem services around the buffer and transition zones in the study area.

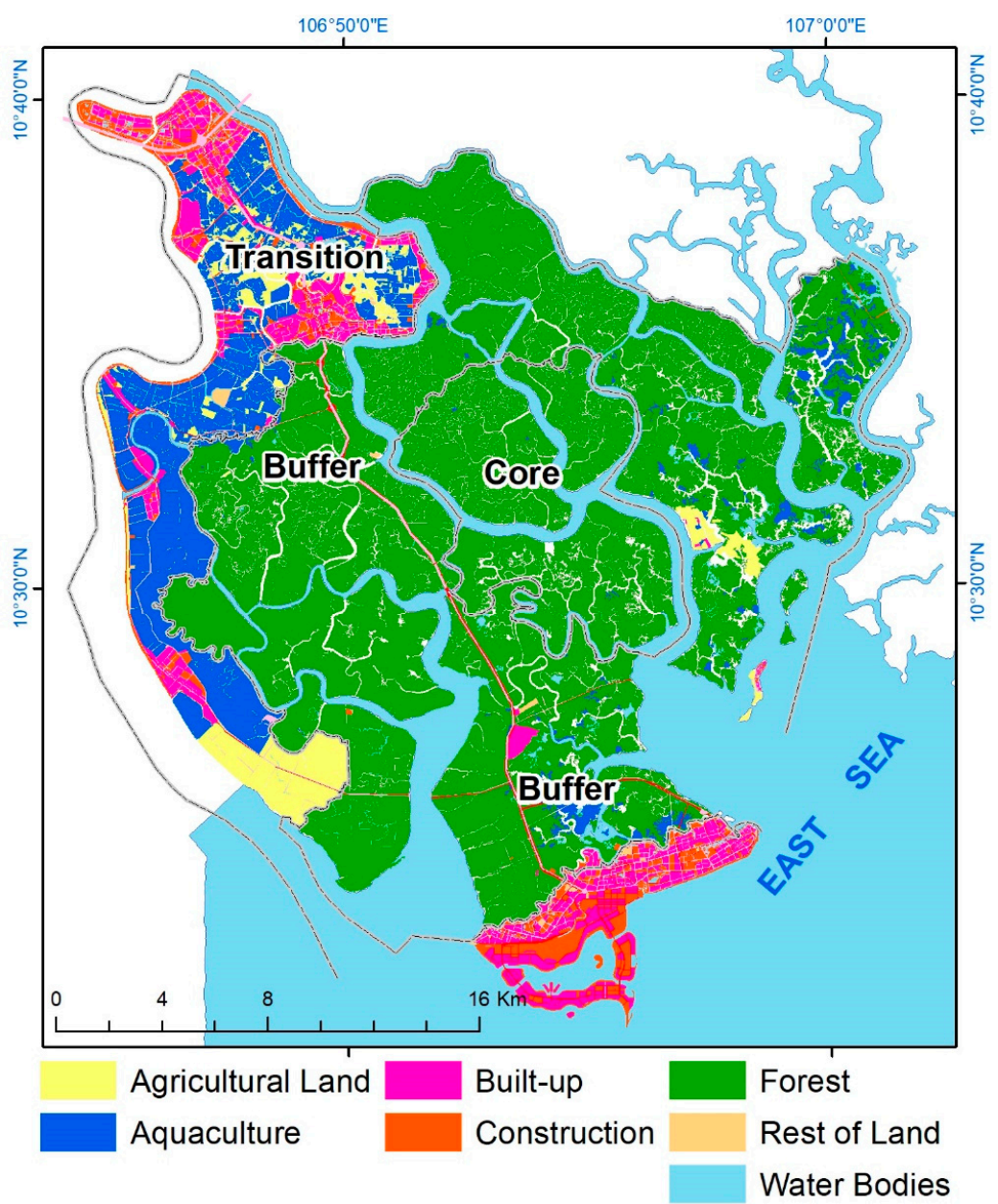

Figure 7. Proposition for land use in Can Gio district (red and pink) with a scale of 1:5000 in 2025 [18].

\section{Conclusions}

The present research explored the potential of applying the multi-temporal NDVI derived from Sentinel through the Google Earth Engine for the mapping and monitoring of mangrove patterns. The Overlap Algorithm was used to explore the signal value of the NDVI, showing the mangrove conditions based on the referenced mangrove populations. Moreover, the validation involved the evaluation of the accuracy of the information classified from the NDVI. The results revealed that the NDVI values greater than 0.3 reflect the mangrove patterns (with $O$-index $>0.85$ ), other than non-mangrove in the study area. The accuracy assessment also revealed, showing substantial agreement, with the Kappa statistic of 0.7 and the overall classification accuracy of $83 \%$ for the NDVI greater than 0.3 .

The spatiotemporal trend of the mangrove forest was characterized using a Mann-Kendal significance test. Furthermore, the examination of land use/land cover change was employed to determine the common parameters impacting on mangrove forest dynamics in the context of economic development. It was revealed that the high density of vegetation was explored in the core and buffer zones, while no vegetation was discovered around the transition zone or residential area. Additionally, a declined area of 2357 ha in total was explored during the period of five years. The variations of mangrove forests mainly occurred in the transition zone and a part of the buffer zone. 
Furthermore, the study focused and demonstrated the potential of time series Sentinel-2 imagery for the discrimination of various mangrove species and for the spatiotemporal analysis of mangroves, which supports the planner, forester and government agencies to strictly implement mitigation measures for the conservation and preservation of mangrove cover. Moreover, Sentinel-derived indices, obtained from the GEE and time-series analysis, are efficient tools for mangrove monitoring and assessment in district scales. They reduced the influence of cloud cover or missing coverage in the study area, located in the tropical region. However, the environments in which mangrove forest growth is complicated were a mixture of wetlands and temporary inundation water covered by the vegetation canopy to some extent, although the high density of mangrove species covered most of study area. Hence, they require an exploration of Synthetic Aperture Radar (SAR) and Optical data for the accurate monitoring of the mangrove pattern, especially in waterbodies covered by mangrove vegetation canopies. Further research, therefore, needs to integrate Sentinel-1A SAR-data, which could provide a solution to enhance and discriminate the structural and geographical features underlying vegetation canopies.

Finally, the study also observed that shrimp farming and built-up development around the transition and buffer zones enacted damage on the long-term sustainability of mangrove forests. Moreover, the development of the sea-encroached urban-tourism zone with an area of 2870 ha in the future will pose a threat to bio-diversity degradation as well as the eco-sustainability of the Biosphere Reserve Area. Furthermore, this study informs the local government on maintaining a balance between developing economic activities and protecting the environment. The proposed planning for tourism development should be strictly adhered to, and prohibited in relation to changes in environmental issues.

Author Contributions: H.T.L., T.V.T., S.G., C.P.T.N., and D.X.T. conceived the idea of the study. T.H.L., H.T.L., and M.B.D. conducted the field work. H.T.L., T.V.T., S.G., C.P.T.N., and D.X.T. processed the data and analysed the results. All authors contributed to the writing and revision of the manuscript. All authors have read and agreed to the published version of the manuscript.

Funding: This study was supported by the Ho Chi Minh City Department of Science and Technology through the project (87/2019/HĐ-QPTKHCN), under entitled: "Studying and Proposing Livelihood Frameworks for Sustainable Development in Can Gio Mangrove Biosphere Reserve".

Conflicts of Interest: The authors declare no conflict of interest.

\section{References}

1. Li, W.; El-Askary, H.; Qurban, M.A.; Li, J.; ManiKandan, K.P.; Piechota, T. Using multi-indices approach to quantify mangrove changes over the Western Arabian Gulf along Saudi Arabia coast. Ecol. Indic. 2019, 102, 734-745. [CrossRef]

2. Pham, T.D.; Yokoya, N.; Bui, D.T.; Yoshino, K.; Friess, D.A. Remote sensing approaches for monitoring mangrove species, structure, and biomass: Opportunities and challenges. Remote Sens. 2019, 11, 230. [CrossRef]

3. Van, T.T.; Wilson, N.; Thanh-Tung, H.; Quisthoudt, K.; Quang-Minh, V.; Xuan-Tuan, L.; Dahdouh-Guebas, F.; Koedam, N. Changes in mangrove vegetation area and character in a war and land use change affected region of Vietnam (Mui Ca Mau) over six decades. Acta Oecologica 2015, 63, 71-81. [CrossRef]

4. Heumann, B.W. Satellite remote sensing of mangrove forests: Recent advances and future opportunities. Prog. Phys. Geogr. 2011, 35, 87-108. [CrossRef]

5. Thomas, N.; Lucas, R.; Bunting, P.; Hardy, A.; Rosenqvist, A.; Simard, M. Distribution and drivers of global mangrove forest change, 1996-2010. PLoS ONE 2017, 12, e0179302. [CrossRef] [PubMed]

6. Liu, K.; Li, X.; Shi, X.; Wang, S. Monitoring mangrove forest changes using remote sensing and GIS data with decision-tree learning. Wetlands 2008, 28, 336. [CrossRef]

7. Lee, S.Y.; Primavera, J.H.; Dahdouh-Guebas, F.; McKee, K.; Bosire, J.O.; Cannicci, S.; Diele, K.; Fromard, F.; Koedam, N.; Marchand, C. Ecological role and services of tropical mangrove ecosystems: A reassessment. Glob. Ecol. Biogeogr. 2014, 23, 726-743. [CrossRef]

8. Pham, L.T.; Vo, T.Q.; Dang, T.D.; Nguyen, U.T. Monitoring mangrove association changes in the Can Gio Biosphere Reserve and implications for management. Remote Sens. Appl. Soc. Environ. 2019, 13, 298-305. [CrossRef] 
9. Food and Agriculture Organization of the United Nations. Loss of Mangroves Alarming; Food and Agriculture Organization of the United Nations: Rome, Italy, 2008.

10. Satyanarayana, B.; Mohamad, K.A.; Idris, I.F.; Husain, M.-L.; Dahdouh-Guebas, F. Assessment of mangrove vegetation based on remote sensing and ground-truth measurements at Tumpat, Kelantan Delta, East Coast of Peninsular Malaysia. Int. J. Remote Sens. 2011, 32, 1635-1650. [CrossRef]

11. Vien, N.N.; Le, V.S.; Miyagi, T.; Kitaya, Y. 25 Years of Mangrove Rehabilitation in Can. Gio District, Ho Chi Minh City, Vietnam. In Annual Report of FY 2002, The Core University Program between Japan Society for the Promotion of Science (JSPS) and National Centre for Natural Science and Technology (NCST); Osaka University: Osaka, Japan, 2003; pp. 79-84.

12. Nam, V.N.; Sinh, L.V.; Miyagi, T.; Baba, S.; Chan, H.T. An overview of Can Gio district and mangrove biosphere reserve. Stud. Can. Gio Mangrove Biosphere Reserve Ho Chi Minh City Vietnam Mangrove Ecosyst. Tech. Rep. 2014, 6, 1-7.

13. Lap, V.N.; Oanh, K.T.T.; Luyen, C.P.; Lan, M.T.N.; Thong, D.T.; Nguyen, H.N.; Quyen, H.T.V. Ecotourism potential of the southeast coastal area of Ho Chi Minh City, Vietnam-Can Gio mangrove forest. J. Biodivers. Environ. Sci. 2018, 12, 1-10.

14. Veettil, B.K.; Ward, R.D.; Quang, N.X.; Trang, N.T.T.; Giang, T.H. Mangroves of Vietnam: Historical development, current state of research and future threats. Estuar. Coast. Shelf Sci. 2019, 218, 212-236. [CrossRef]

15. Quyết định 430/QĐ-TTg phê duyệt Điều chỉnh quy hoạch chung tại Thành phố Hồ Chí Minh. Available online: https://thuvienphapluat.vn/van-ban/dau-tu/Quyet-dinh-430-QD-TTg-2020-phe-duyet-dieu-chinhcuc-bo-quy-hoach-chung-xay-dung-Ho-Chi-Minh-438656.aspx (accessed on 27 March 2020).

16. Prime Minister, D. Quyết định số 2631/QĐ-TTg về việc phê duyệt Quy hoạch tổng thể phát triển kinh tế - xã hội thành phố Hồ Chí Minh đến 2020, tầm nhìn đến 20252013 . Available online: https://thuvienphapluat.vn/van-ban/Xay-dung-Do-thi/Quyet-dinh-2631-QD-TTg-2013-quy-hoachtong-the-phat-trien-kinh-te-xa-hoi-Ho-Chi-Minh-den-2020-218402.aspx (accessed on 27 March 2020).

17. HCMC People's Committee, H. Quyết định 188/2003/QĐ-UB quy hoạch chi tiết sử dụng đất Khu đô thị du lịch lấn biển Cần Giờ-thành phố Hồ Chí Minh 2003. Available online: https://thuvienphapluat.vn/van-ban/xay-dung-do-thi/Quyet-dinh-188-2003-QD-UB-quy-hoachchi-tiet-su-dung-dat-Khu-do-thi-du-lich-lan-bien-Can-Gio-thanh-pho-Ho-Chi-Minh-34386.aspx (accessed on 27 March 2020).

18. HCMC People's Committee, H. QĐ số 3800/QĐ-UBND ngày 05/09/2018 của UBNDTP Về duyệt Đồ án QHPK tỷ lệ 1/5000 Khu đô thị du lịch biển Cần Giờ quy mô 2.870 ha, tại xã Long Hòa và thị trấn Cần Thạnh, huyện Cần Giờ 2018. Available online: http://congbao.hochiminhcity.gov.vn/tin-tuc-tong-hop/\%C4\%91ieuchinh-cuc-bo-\%C4\%91o-an-quy-hoach-phan-khu-ty-le-1-5000-khu-\%C4\%91o-thi-du-lich-bien-can-giotai-xa-long-hoa-va-thi-tran-can-thanh-huyen-can-gio (accessed on 27 March 2020).

19. Nardin, W.; Locatelli, S.; Pasquarella, V.; Rulli, M.C.; Woodcock, C.E.; Fagherazzi, S. Dynamics of a fringe mangrove forest detected by Landsat images in the Mekong River Delta, Vietnam. Earth Surf. Process. Landf. 2016, 41, 2024-2037. [CrossRef]

20. Zhang, X.; Tian, Q. A mangrove recognition index for remote sensing of mangrove forest from space. Curr. Sci. 2013, 105, 1149-1154.

21. Chen, B.; Xiao, X.; Li, X.; Pan, L.; Doughty, R.; Ma, J.; Dong, J.; Qin, Y.; Zhao, B.; Wu, Z. A mangrove forest map of China in 2015: Analysis of time series Landsat 7/8 and Sentinel-1A imagery in Google Earth Engine cloud computing platform. ISPRS J. Photogramm. Remote Sens. 2017, 131, 104-120. [CrossRef]

22. Omar, H.; Misman, M.A.; Linggok, A.V. Characeterizing and monitoring of mangroves in Malaysia using Landsat-Based spatial-spectral variability. Earth Enviromental Sci. 2018, 169. [CrossRef]

23. Cardenas, N.Y.; Joyce, K.E.; Maier, S.W. Monitoring mangrove forests: Are we taking full advantage of technology? Int. J. Appl. Earth Obs. Geoinf. 2017, 63, 1-14. [CrossRef]

24. Wicaksono, P. Mangrove above-ground carbon stock mapping of multi-resolution passive remote-sensing systems. Int. J. Remote Sens. 2017, 38, 1551-1578. [CrossRef]

25. Bunting, P.; Rosenqvist, A.; Lucas, R.; Rebelo, L.-M.; Hilarides, L.; Thomas, N.; Hardy, A.; Itoh, T.; Shimada, M.; Finlayson, C. The global mangrove watch-A new 2010 global baseline of mangrove extent. Remote Sens. 2018, 10, 1669. [CrossRef]

26. Wang, D.; Wan, B.; Qiu, P.; Su, Y.; Guo, Q.; Wang, R.; Sun, F.; Wu, X. Evaluating the performance of sentinel-2, landsat 8 and pléiades- 1 in mapping mangrove extent and species. Remote Sens. 2018, 10, 1468. [CrossRef] 
27. Yoshino, K.; Miyagi, T.; Kitaya, Y.; Vien, N.N. Changes of the land cover and land use in Can Gio area, Vietnam from 1997 to 2003. In Annual Report of FY 2007, The Core University Program between Japan Society for the Promotion of Science (JSPS) and Vietnamese Academy of Science and Technology (VAST); Osaka University: Osaka, Japan, 2008; pp. 219-223.

28. Luong, N.; Tu, T.; Khoi, L.; Hoan, N. Biomass estimation and mapping of CG Mangrove Biosphere Reserve in South of Viet Nam using ALOS-2 PALSAR-2 data. Appl. Ecol. Environ. Res. 2019, 17, 15-31. [CrossRef]

29. Muhdoni, F.F.; Sambah, A.B.; Mahmudi, M.; Wiadnya, D.G.R. Comparison of Different Vegetation Indices for assessing Mangrove Density using Sentinel-2 Imagery. Int. J. Geomate 2018, 14, 42-51. [CrossRef]

30. Zhang, X.; Treitz, P.M.; Chen, D.; Quan, C.; Shi, L.; Li, X. Mapping mangrove forests using multi-tidal remotely-sensed data and a decision-tree-based procedure. Int. J. Appl. Earth Obs. Geoinf. 2017, 62, $201-214$. [CrossRef]

31. Luong, N.V.; Tateishi, R.; Hoan, N.T. Analysis of an impact of succession in mangrove forest association using remote sensing and GIS technology. J. Geogr. Geol. 2015, 7, 106. [CrossRef]

32. Gupta, K.; Mukhopadhyay, A.; Giri, S.; Chanda, A.; Majumdar, S.D.; Samanta, S.; Mitra, D.; Samal, R.N.; Pattnaik, A.K.; Hazra, S. An index for discrimination of mangroves from non-mangroves using LANDSAT 8 OLI imagery. MethodsX 2018, 5, 1129-1139. [CrossRef] [PubMed]

33. Ahmad, F.; Goparaju, L.; Qayum, A. Geo-spatial perspective of vegetation health evaluation and climate change scenario in India. Spat. Inf. Res. 2019, 27, 497-504. [CrossRef]

34. Rouse, J.W., Jr.; Haas, R.H.; Schell, J.A.; Deering, D.W. Monitoring Vegetation systems in the Great Plains with ERTS. NASA Spec. Publ. 1974, 1, 309-317.

35. Giri, C.; Ochieng, E.; Tieszen, L.L.; Zhu, Z.; Singh, A.; Loveland, T.; Masek, J.; Duke, N. Status and distribution of mangrove forests of the world using earth observation satellite data. Glob. Ecol. Biogeogr. 2011, 20, 154-159. [CrossRef]

36. Cissell, J.R.; Delgado, A.M.; Sweetman, B.M.; Steinberg, M.K. Monitoring mangrove forest dynamics in Campeche, Mexico, using Landsat satellite data. Remote Sens. Appl. Soc. Environ. 2018, 9, 60-68. [CrossRef]

37. Patel, N.N.; Angiuli, E.; Gamba, P.; Gaughan, A.; Lisini, G.; Stevens, F.R.; Tatem, A.J.; Trianni, G. Multitemporal settlement and population mapping from Landsat using Google Earth Engine. Int. J. Appl. Earth Obs. Geoinf. 2015, 35, 199-208. [CrossRef]

38. Hird, J.N.; DeLancey, E.R.; McDermid, G.J.; Kariyeva, J. Google Earth Engine, open-access satellite data, and machine learning in support of large-area probabilistic wetland mapping. Remote Sens. 2017, 9, 1315. [CrossRef]

39. Johansen, K.; Phinn, S.; Taylor, M. Mapping woody vegetation clearing in Queensland, Australia from Landsat imagery using the Google Earth Engine. Remote Sens. Appl. Soc. Environ. 2015, 1, 36-49. [CrossRef]

40. Miyagi, T.; Nam, V.N.; Le Van Sinh, M.K.; Saitoh, A.; Hayashi, K.; Otomo, M. Further study on the mangrove recovery processes in Can Gio, Viet Nam. Stud. Can. Gio Mangrove Biosphere Reserve Ho Chi Minh City Viet Nam 2014, 6, 15-30.

41. Hung, T.T.; Huyen, D.T.; Tu, T.A.; Desmet, M. Presence of trace elements in sediments of Can Gio mangrove forest, Ho Chi Minh city, Vietnam. Vietnam J. Earth Sci. 2018, 41, 21-35. [CrossRef]

42. Viet, L.N.; Trong, T.T.; Xuan, H.T.; Luu, T.T.H. The Analysis of Mangrove Forest Changes Period of 20 Years in Can Gio Biosphere Reserve, Viet Nam Using Remote Sensing and GIS Technology. Sci. Forecast. 2018, 1, 1021.

43. Tobler, W. Resolution, resampling, and all that. Build. Databases Glob. Sci. 1988, 12, 9-137.

44. Schmid, J.N. Using Google Earth Engine for Landsat NDVI Time Series Analysis to Indicate the Present Status of Forest Stands; Georg-August-Universität Göttingen: Basel, Switzerland, 2017.

45. Akhrianti, I. Spatial Distribution of Mangrove in Kelapan Island South Bangka regency. Adv. Eng. Res. 2018, 167. [CrossRef]

46. Methodology Used for the Classification of Vegetation Biodiversity. Available online: https://www. yourarticlelibrary.com/biodiversity/methodology-used-for-the-classification-of-vegetation-biodiversity/42729 (accessed on 25 April 2020).

47. Sahebjalal, E.; Dashtekian, K. Analysis of land use-land covers changes using normalized difference vegetation index (NDVI) differencing and classification methods. Afr. J. Agric. Res. 2013, 8, 4614-4622.

48. Zhu, E.; Deng, D.; Nargesian, F.; Miller, R.J. Josie: Overlap set similarity search for finding joinable tables in data lakes. In Proceedings of the 2019 International Conference on Management of Data, Amsterdam, The Netherlands, 30 June 30-5 July 2019; pp. 847-864. 
49. Ahmed, M.A. Eliciting Correlations between Components Selection Decision Cases in Software Architecting. Bachelor's Thesis, Mälardalen University, Västerås, Sweden, 2019.

50. Vijaymeena, M.K.; Kavitha, K. A survey on similarity measures in text mining. Mach. Learn. Appl. Int. J. 2016, 3, 19-28.

51. Cao, X.; Lu, H.; Ren, M.; Jiao, L. Non-overlapping classification of hyperspectral imagery with superpixel segmentation. Appl. Soft Comput. 2019, 83, 105630. [CrossRef]

52. Kvalseth, T.O. Note on Cohen's Kappa. Psychol. Rep. 1989, 65, 223-226. [CrossRef]

53. Mchugh, M.L. Interrater Reliability: The Kappa Statistic. Biochem. Medica 2012, 22, 276-282. [CrossRef]

54. Alcaraz-Segura, D.; Liras, E.; Tabik, S.; Paruelo, J.; Cabello, J. Evaluating the consistency of the 1982-1999 NDVI trends in the Iberian Peninsula across four time-series derived from the AVHRR sensor: LTDR, GIMMS, FASIR, and PAL-II. Sensors 2010, 10, 1291-1314. [CrossRef]

55. Ahmad, I.; Tang, D.; Wang, T.; Wang, M.; Wagan, B. Precipitation trends over time using Mann-Kendall and spearman's rho tests in swat river basin, Pakistan. Adv. Meteorol. 2015, 2015. [CrossRef]

56. Feidas, H.; Noulopoulou, C.; Makrogiannis, T.; Bora-Senta, E. Trend analysis of precipitation time series in Greece and their relationship with circulation using surface and satellite data: 1955-2001. Theor. Appl. Climatol. 2007, 87, 155-177. [CrossRef]

57. Gocic, M.; Trajkovic, S. Analysis of changes in meteorological variables using Mann-Kendall and Sen's slope estimator statistical tests in Serbia. Glob. Planet. Chang. 2013, 100, 172-182. [CrossRef]

58. Partal, T.; Küçük, M. Long-term trend analysis using discrete wavelet components of annual precipitations measurements in Marmara region (Turkey). Phys. Chem. Earth Parts ABC 2006, 31, 1189-1200. [CrossRef]

59. Shadmani, M.; Marofi, S.; Roknian, M. Trend Analysis in Reference Evapotranspiration Using Mann-Kendall and Spearman's Rho Tests in Arid Regions of Iran. Water Resour. Manag. 2012, 26, 211-224. [CrossRef]

60. Fassnacht, F.E.; Schiller, C.; Kattenborn, T.; Zhao, X.; Qu, J. A Landsat-based vegetation trend product of the Tibetan Plateau for the time-period 1990-2018. Sci. Data 2019, 6, 78. [CrossRef]

61. Tran, T.V.; Tran, D.X.; Myint, S.W.; Huang, C.; Pham, H.V.; Luu, T.H.; Vo, T.M. Examining spatiotemporal salinity dynamics in the Mekong River Delta using Landsat time series imagery and a spatial regression approach. Sci. Total Environ. 2019, 687, 1087-1097. [CrossRef]

62. Otache, M.Y.; Bakir, M.; Li, Z. Analysis of stochastic characteristics of the Benue River flow process. Chin. J. Oceanol. Limnol. 2008, 26, 142-151. [CrossRef]

63. Kisi, O.; Ay, M. Comparison of Mann-Kendall and innovative trend method for water quality parameters of the Kizilirmak River, Turkey. J. Hydrol. 2014, 513, 362-375. [CrossRef]

64. Duke, N.; Nagelkerken, I.; Agardy, T.; Wells, S.; Van Lavieren, H. The Importance of Mangroves to People: A Call to Action; United Nations Environment Programme World Conservation Monitoring Centre: Cambridge, UK, 2014; ISBN 92-807-3397-4.

65. Hong, P.N. Reforestation of mangroves after severe impacts of herbicides during the the Viet Nam war: The case of Can Gio. Unasylva FAO 2001, 52, 57-60.

66. Nam, V.N.; Sinh, L.V. Destruction, restoration and management of Can Gio Mangroves. Stud. Can. Gio Mangrove Biosphere Reserve Ho Chi Minh City Vietnam Mangrove Ecosyst. Techinical Rep. 2014, 6, 9-13.

67. Tuan, V.Q.; Kuenzer, C. Can Gio Mangrove Biosphere Reserve Evaluation 2012: Current Status, Dynamics, and Ecosystem Services; IUCN Viet Nam Country Office: Hanoi, Viet Nam, 2012.

68. Leschine, T.M.; Wellman, K.F.; Green, T.H. The Economic Value of Wetlands: Wetlands' Role in Flood Protection in Western Washington; Washington State Department of Ecology: Bellevue, WA, USA, 1997.

69. Mithapala, S. Mangroves: Coastal Ecosystem Series (Volume 2); IUCN Ecosystems and Livelihoods Group Asia: Colombo, Sri Lanka, 2008.

70. Barbier, E.B.; Hacker, S.D.; Kennedy, C.; Koch, E.W.; Stier, A.C.; Silliman, B.R. The value of estuarine and coastal ecosystem services. Ecol. Monogr. 2011, 81, 169-193. [CrossRef]

(C) 2020 by the authors. Licensee MDPI, Basel, Switzerland. This article is an open access article distributed under the terms and conditions of the Creative Commons Attribution (CC BY) license (http://creativecommons.org/licenses/by/4.0/). 